\title{
A STUDY OF INTERACTION IN THE ENGLISH CLASSROOM
}

\author{
Abhimanyu Kumar. $S$ \\ Assistant Professor of English, New Horizon College, Bangalore, India. \\ thalaabhimanyu@gmail.com
}

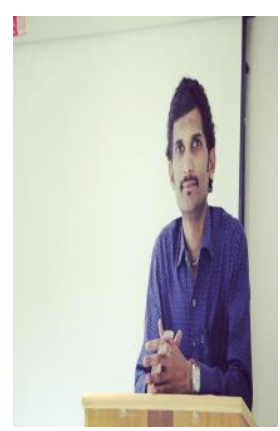

Keywords:

Effective Teaching-Learning,

Effective Communication,

Personality Development,

\begin{abstract}
A B S T RA C T
The English Language plays a vital role in the overall personality development of the learners by making them effective communicators and highly skilled in tackling real-life situations. The English teacher should move towards a more effective teaching-learning-testing process. The outcome is the integral formation of the whole person. Therefore, our focus should not just be on teaching as an end in itself, but teaching as a means. The very focus of the English teacher should be on the specific outcomes of learning by teaching them the core basic human values like hard working, broad-mindedness, ability, courage, forgiveness and honesty. If the English teacher wants to make his teaching effective and easily accessible to his students, he should take care of their needs and try to understand their learning levels in order to reach their expectancies.
\end{abstract}

Citation: Abhimanyu Kumar. S (2018). A Study Of Interaction In The English Classroom. International Journal of Advanced Multidisciplinary Scientific Research (IJAMSR ) ISSN:2581-4281 Vol 1, Issue4, June 2018, \#Art.217, pp67-71

\section{Introduction}

According to Interaction - Based Instruction, samples of the target language becomes available to the learner for inter-language construction through classroom interaction. Through carefully designed classroom interaction activities, involving various forms of more or less realistic practice, learners can become skilled at actually doing the things they have been taught about. The problem is that the learners don't know instinctively how to interact with each other.
This research presents a number of teaching techniques that addresses the problems that EFL teachers face to provide an interactive classroom condition. These techniques are the strategies of classroom interaction, such as questioning techniques and modification through cooperative methods of learning. 


\section{International Journal of Advanced Multidisciplinary Scientific Research (IJAMSR) ISSN:2581-4281}

\section{Discussion}

One of the ways of teaching English language or any language is that, a teacher needs to sensitize the students by taking them into deep literature and evoke the sense of expressions in them and then conduct activities, where you allow them to express first and then a teacher needs to reflect on the results.

The student now is, exposed to technology in varieties and hence they expect something different and entertainment in the classroom. A teacher can bring vocabulary and word building games and at least two proverbs and an idiom in an hour's class.

All human action involves three aspects; Planning or setting out, Executing the plan and Looking at the results. After all these aspects reflections takes a role in a teacher.

Before we deal with classroom interaction it would be apt to see the problems faced by a teacher today. An average Indian classroom is overcrowded, and facilities are grossly inadequate. In such circumstance, to maintain discipline is the highest task for a teacher. Above all, any given class consists of heterogeneous learners, belonging to different economic, social and educational backgrounds. Yet another hurdle the English teacher has to contend with is, the students' mother tongue constantly influencing them in the course of their learning English.

Cooperative learning is opposed to individualism and competitive learning, which has been proclaimed as an effective instructional approach which involves the characteristics of learner-centered approaches.
Cooperative learning requires learners to work in groups to achieve a common goal (Chafe, 1998). Working together maximizes opportunities for studentstudent interaction with meaningful input and output in a supportive environment.

According to Chomsky and other modern linguists, a native finds it difficult to learn a foreign language on the basis of his accent and thinking. A native thinks in his mother tongue and tries to express in English and you find him having the accent of his mother tongue. One should think in English and express in English, so that the accent and the content is clear. Conducting exercises on this can really help students in improving the language and communication skills.

A valuable classroom technique that can effectively be practiced is group work. A teacher can give an interesting topic of students' interest and divide the class into 5 or more groups and let students to discuss and come out with new ideas and subjects. According to Palani, seeing each other as resource is vital for group dynamics to prosper. Group work stimulates group members to talk in the target language (under good monitoring).

Six specific skill areas have been identified to activate and monitor reading comprehension. Some of the strategies they have suggested for the improvement of critical reading skills are:
1. Previewing
2. Annotating
3. Summarizing
4. Analyzing
5. Re-reading
6. Responding 


\section{International Journal of Advanced Multidisciplinary Scientific Research (IJAMSR) ISSN:2581-4281}

\section{Previewing}

By asking students to preview a section of the text, the teacher makes them gather as much information about the text as they can before they actually read the text. They may ask themselves questions such as follows:

- What is my purpose in reading this text?

- What does the title tell me?

- Who is the author? What do I know about his /her stance on the issues that I am reading about?

- How is the text structured? Does it provide any clue to the organization of the content? Do the section headings and the opening sentence give me a good idea about the main theme in the piece?

The teacher then asks the students to make predictions involving their drawing inferences. In reading, sometimes predicting is more important than decoding. So instead of concentrating on each word and trying to understand what it "means", readers may rely on all their language and discourse knowledge to predict what a text is all about. These steps will help activate the relevant background knowledge.

\section{Annotating}

While reading, the teacher advises students to make notes along the margins. This enables the students to create an active relationship with what they are reading by talking back to the text in its margin. The teacher also asks them to see if the text confirms the predictions they made at the previewing stage. The students mark points, sub ides, key terms or the unfamiliar words and confusing parts, which warrant rereading later.

\section{Summarizing}

At this stage, the teacher advices the students to summarize the essence of what they have grasped from their reading of the text. They are advised to do so in one tenth of the volume of the original text. This is a valuable way of checking their understanding.

\section{Analyzing}

This step involves breaking the text into parts.

- Analyzing what the writer presents as evidence to support the point he/she is making.

- Analyzing the unstated and underlying assumptions on which the text is based.

- Analyzing the author's source to back up what he/she states.

- Analyzing the author's bias; in other words, the experiences in his / her background which may have led him to hold the viewpoint.

\section{Rereading}

The teacher initially tells the students that good readers reread a text several times until they gain a good understanding of it. She encourages them to read the text at least three times for maximum understanding.

\section{Responding}

At this stage, the teacher asks the students to respond to their reading of the text by writing or talking about it. 
This not only reinforces their reading process, but also facilitates a better understanding of the text.

\section{Reading for meaning}

While leading the students through all the above stages, the teacher plays a the role of an effective interface by helping them speculate on :

- The overall purpose of the author

- The audience intended by the writer

- The assumptions the author makes in putting forward his or her point of view

- The key ides running through the text

- The author's tone

To make a class interaction lively, interesting and purposeful a teacher can follow these techniques to make an impact:
a) Pair Work
b) Role Plays
c) Poster Presentation
d) Anonymous Stories
e) Story building
f) Marketing Strategies
g) Activity Games

However, a teacher must concentrate on three stages, i.e., pretext, Text and Context for teaching language and literature.

\section{Pre-Text}

Ask students to think and react with the prior knowledge from their formal or informal learning.

\section{Text}

Explain or paraphrase the text from the text.

\section{Context}

Relate the text to the contemporary world.

After this you can always get written scripts on the topic and later reflect upon the critical Analysis.

\section{Conclusion}

These guidelines can help teachers to become more exploratory in their interactions with students of varying language skills, intellectual levels, and dispositions. They can serve as a challenge, especially to persevere and novice teachers who can expect to have ELLs in their classrooms. New teachers may not readily anticipate the needs of their ELLs, although teacher education programs have put greater emphasis on meeting the needs of culturally and linguistically diverse learners. Still, the challenge to use ordinary words to accomplish extraordinary things remains. The Response Protocol is one way to support teachers' efforts to increase engagement among ELLs in classroom discourse. 
https://doi.org/10.31426/ijamsr.2018.1.4.217

I J A M S R

International Journal of

Advanced Multidisciplinary Scientific Research (IJAMSR) ISSN:2581-4281

\section{References}

1. Contribution and Achievement of T.S.Eliot by Rajesh Kumar, Chandigarh

2. Individual differences in strategy use in second language reading and testing, Anderson, 1991

3. Facilitating ESL reading by teaching text structure, Carell,P.L.1985

4. Essential Speaking Skills : A Hand Book for English Language Teachers : London,Baker,J and Heather Westrup. 2006

5. A Course in Language Teaching: Practice and Theory: Cambridge: Cambridge University Press 